\title{
HORMONES OF PITUITARY-GONADAL AXIS AND HISTOLOGY OF PITUITARY GLAND FOLLOWING ORAL TREATMENT OF MALE WISTAR RATS WITH GLYPHOSATE
}

Popoola S.O* and Sakpa C.L.

Department of Anatomy, Ekiti State University, Ado-Ekiti, ${ }^{*}$ and University of Benin, Benin-City, Nigeria.

*Corresponding Author: Sunday Ogunsuyi Popoola, Department of Anatomy, Ekiti State University, Ado-Ekiti, Nigeria 360001 PMB 5363. Email: ogunsuyipopoola@yahoo.com

Received date: May $14^{\text {th }} 2018$, Accepted date: June $01^{\text {st }}$ 2018. Published date: June $30^{\text {th }} 2018$.

\begin{abstract}
There are numerous endocrine disrupting chemicals across the globe among which is the contentious organophosphate called glyphosate. The aim was to analyze the effects of glyphosate on Wistar rat's pituitary gland and pituitary-gonadal axis. Specific objectives determined male reproductive hormones of Wistar rats exposed to glyphosate; demonstrated possible endocrine disruptive action of glyphosate on Wistar rats and determined effects of glyphosate on histology of pituitary gland. Fifteen male adult Wistar rats of 200g and above used for the study were randomly assigned into three groups A, B and C of 5 rats in each. Group A (control) gavaged with only distilled water. Group B (low dose) and Group C (high dose) were gavaged with 400mg and $2000 \mathrm{mg}$ of glyphosate/kg body weight/day respectively. All the rats were treated for 60 days before sacrificing, collection of blood sample and harvesting of tissue for analysis. Collated data were entered into Statistical Package for Social Scientists (version 21) for t-test and test of significance $(\mathrm{p}<0.05)$. Both follicle stimulating hormone and testosterone were significantly decreased in treated rats. The levels of luteinizing hormone, prolactin, oestrogen, progesterone and testosterone/oestrogen ratio statistically increased among treated groups. Adenohypophysis in Group B rats illustrated cellular hyperplasia with mitotic bodies while those of Group C demonstrated fewer cells that are widely separated by connective tissue. This study established glyphosate as an endocrine disrupting chemical. Histological slides of the pituitary gland of treated rats showed some level of abnormality. High-resolute imaging techniques were suggested for better imaging.
\end{abstract}

Keywords: Glyphosate; Histopathology; Pituitary-gonadal axis; Reproductive dysfunction.

\section{Introduction}

Different chemicals are used in day-to-day activities of humans across the globe. The use is either for positive or negative effects and in the process contamination can occur. Contamination is broadly from occupational or environmental practices. Of note is Endocrine Disrupting Chemicals (EDCs) which are compounds that alter the normal functioning of the endocrine system of both animals and humans. ${ }^{1}$ EDC first coined in 1993 when researchers were looking into certain chemicals that mimicked endogenous hormones altering the homeostasis of organ-systems. ${ }^{2}$ The USA forged ahead and in 1998 established Endocrine Disruptor Screening Program (EDSP) to evaluate chemicals having deleterious effects on endocrine homeostasis. In the like manner, efforts were made in Europe to identify individual constituents of chemical packages in order to evaluate their toxic effects. EDCs can either be natural (like phytoestrogens) or synthetic/artificial. Among the artificial ones are chemicals used in food, pharmaceutical, textile, wooden, plastic, oil and gas industries. Herbicides and pesticides are utilized against weeds and pests to promote agricultural produce for food and other industries. Atrazine $\left(\mathrm{C}_{8} \mathrm{H}_{14} \mathrm{CIN}_{5}\right.$; Triazine compound), an herbicide had been implicated to disrupt endocrine (hormone) system. ${ }^{3}$ Paraquat $\left(\mathrm{C}_{12} \mathrm{H}_{14} \mathrm{~N}_{2}\right.$; quaternary nitrogen compound) is another widely used herbicide which had earlier been established as EDC. Organophosphates are also known to disrupt 
endocrine system. The world most widely used unspecific herbicide called glyphosate is an organophosphate compound which had demonstrated some degrees of hormone disruption according to studies in the USA, Brazil, France and other countries. ${ }^{4-7}$ Glyphosate $\left(\mathrm{C}_{3} \mathrm{H}_{8} \mathrm{NO}_{5} \mathrm{P}\right.$;

$N$-Phosphonomethylglycine) in most cases bears Isopropylamine ammonium salt which aids its solubility though does not affect its chemical properties, hence, the idea of glyphosate base herbicides $(\mathrm{GBH})$. GBHs are equally known for their pesticidal properties. ${ }^{8-10}$ In plants, glyphosate is absorbed through the leaves and roots, translocates into all parts and thereby inhibits enolpyruvylshikimate-3-phosphate synthase (EPSPS) necessary for the production of aromatic amino acids, auxin, phytoalexins, folic acid, lignin, plastoquinones and many other secondary products. ${ }^{11}$ The herbicide is, most times, sprayed on plants with relatively high levels permeating as residues in food products, water and animal feeds apart from direct human exposure through the skin and lungs. ${ }^{12}$ Contamination frequently occurs when rain falls directly after application of glyphosate and when flood increases river and lagoon sediment load. Urban runoff and wastewater treatment effluent can also explain considerable glyphosate input into rivers. ${ }^{13}$

In animals, glyphosate activates protein kinase $\mathrm{C}$ and the mitogen-activated protein kinases in eliciting calcium $\left(\mathrm{Ca}^{2+}\right)$ influx and cell death. ${ }^{14}$ Glyphosate increases cytosolic $\mathrm{Ca}^{2+}$ concentration by opening Ltype-voltage-dependent $\mathrm{Ca}^{2+}$ channels, thereby permitting $\mathrm{Ca}^{2+}$ to enter the cells, as well as targeting the endoplasmic reticulum molecule called inositol triphosphate $\left(\mathrm{IP}_{3}\right)$ and ryanodine receptors which are both $\mathrm{Ca}^{2+}$ release channels, leading to $\mathrm{Ca}^{2+}$ release and overload within the cells, thereby activating cell death. ${ }^{11}$ At the same research, Shaner discovered glyphosate to down-regulate the functional integrity of the activities of glutathione which is the tissue's own antioxidant consistent with oxidative stress, and increases the amounts of thiobarbituric acid reactive species and protein carbonyls, which had been implicated in oxidative impairment from reactive oxygen species to lipids and proteins respectively. In an experiment, glyphosate intoxication was due to $\mathrm{Ca}^{2+}$ overload with resultant cell signaling fault and a stress response in defence against depleted antioxidant, contributing to the death of Sertoli cells with resultant male infertility. ${ }^{15,16}$ Increasing $\mathrm{Ca}^{2+}$ concentration in the cytoplasm in turn caused $\mathrm{Ca}^{2+}$ influx into the mitochondria and nuclei leading to either programmed apoptotic or inflammatory necrotic cell death. ${ }^{17}$ In nuclei, $\mathrm{Ca}^{2+}$ modulates gene transcription and nucleases that regulate apoptosis that involves fragmentation of deoxyribonucleic acid (DNA). ${ }^{18}$ Glyphosate toxicity in Wistar rats (aged 6weeks and above) was reported to induce deleterious reproductive effects including diminution in daily sperm production during adulthood, increase in abnormal sperms, low serum testosterone level at puberty and delay in vaginal canal opening in exposed female offsprings. ${ }^{19}$

Now, scientific studies are beginning to reveal the ecotoxicity effect on exposure to experimental animals and humans. In some animal studies, there were conflicting results about the safety of glyphosate: some documented carcinogenic, mutagenic, metabolic effects and hormone disruption while others described its effects on fertility even at low concentration compared to the dose being used in dealing with weeds in agriculture. ${ }^{5}$ In the past, glyphosate was believed to be relatively non-toxic to mammals and widely marketed by the various manufacturers, as safe. $^{20,}{ }^{21}$ Germany played the European Union Rapporteur Member State (EURMS) and submitted their glyphosate renewal assessment report (GRAR) to the European Food Safety Authority (EFSA), recommending formal approval of glyphosate for use in Europe with increase in the acceptable daily intake (ADI). Notwithstanding, the recommendation from Germany was said to be scandalous amid overwhelming evidence of ecotoxicity leading to banning of glyphosate in some countries. These countries include: Denmark, El Salvador, France, Sri Lanka, Netherlands, and Brazil, one of the largest growers of glyphosate-tolerant genetically modified crops. Latest news on Genetically Modified Organization (GMO) food, GMO crops and GMO labeling had marked glyphosate as EDC. ${ }^{22}$ Contrarily, Germany made her own report: the available data do not show carcinogenic or mutagenic properties of glyphosate nor that glyphosate was toxic to fertility, reproduction or intra-uterine development in laboratory animals. Germany later recommended the re-approval of glyphosate for use in Europe with an increase in the acceptable daily intake (ADI) from 0.3 to $0.5 \mathrm{mg}$ per $\mathrm{kg}$ body weight per day with undisclosed reasons. ${ }^{23}$

With the various conflicting evidence of ecotoxicity and effects of glyphosate on humans, this study was set to join other researchers in determining male 
reproductive hormone profile of Wistar rats exposed to glyphosate. Specifically, the study was designed to demonstrate possible endocrine disruptive action of glyphosate on Wistar rats and determine potential effects of glyphosate on the histology of pituitary gland. Going through the literature and web, researches on the possible effects of glyphosate on the histology of pituitary gland coupled with hormone analysis were scarce.

\section{Materials and Methods}

This study was approved and carried out according to the international standard adopted by the Department of Anatomy, University of Benin, Benin-City, Nigeria. Fifteen adult male Wistar rats were used for this study weighed $200 \mathrm{~g}$ and above. The rats were randomly assigned into three groups $\mathrm{A}, \mathrm{B}$ and $\mathrm{C}$ of 5 rats each. Rat cannula was employed for gavaging. Group A was control and gavaged with only distilled water. Group B was low dose and gavaged with $400 \mathrm{mg}$ of glyphosate $/ \mathrm{kg}$ body weight/day. Group C was high dose and gavaged with $2000 \mathrm{mg}$ of glyphosate/kg body weight/day. Dosing was based on the $\mathrm{LD}_{50}$ of Glyphosate. The safest tolerant concentration to be administered was given to high dose group as half of glyphosate $\mathrm{LD}_{50}$ : 2000 $\mathrm{mg} / \mathrm{kg} /$ day. ${ }^{24,}{ }^{25}$ The low dose was assigned as $1 / 10^{\text {th }}$ of the $\mathrm{LD}_{50}$. All the rats were gavaged for 60days based on the spermatogenic cycle of Wistar rat. ${ }^{26} \mathrm{By}$ midline abdominal approach, a midline incision was made on the ventral abdominal wall and deepened to enter the abdominal cavity. Blood sample for hormone analysis was then collected from the inferior vena cava. Neutral formol saline solution was injected through the superior orbital fissure as a form of cavity embalming before decapitation for special harvesting of pituitary gland. A week after decapitation, with the use of bone nibbler, bone cutter and other dissecting tools, the sella turcica (pituitary fossa) was identified and the gland removed enmasse and preserved in neutral formol saline solution. The glands were processed for light microscopy. The hormone analysis (follicle stimulating hormone $\mathrm{FSH}$, luteinizing hormone $\mathrm{LH}$, prolactin, testosterone, oestrogen and progesterone) was carried out using enzyme-linked immunosorbent assay (ELISA). ${ }^{27}$ The data on hormone profile were collated and entered into Statistical Package for Social Scientists (SPSS version 21) software for t-test and test of significance set at $p$ $<0.05$. Results were represented in words, tables and figures using Microsoft office software.

\section{Results}

\section{Hormone profile}

There were decreases in follicle stimulating hormone (FSH) and testosterone levels; both of which were statistically-significant when compared to control group A rats. However the levels of luteinizing hormone (LH), prolactin, oestrogen, progesterone and testosterone/oestrogen ratio increased among the treatment groups. Most of these increases were statistically-significant especially, in group $\mathrm{C}$ when compared to control group A. Besides, the increases were dose-dependent (see Table).

\section{Histological studies of pituitary gland}

The slide of adenohypophysis for group A shows normal histological features illustrating the pieces of acidophils, basophils and few chromophobes with blood vessels and connective tissue spaces (Fig. 1). However, slide of group B (Fig. 2) shows cellular hyperplasia with mitotic bodies, and a compact and well-defined trabeculae separated by blood vessels. Group C slide (Fig. 3) shows fewer cells that are widely separated by connective tissue when compared to the control slide.

Table: Hormone profile of Wistar rats

\begin{tabular}{|c|c|c|c|}
\hline Hormone & $\begin{array}{l}\text { Group A } \\
\text { (Control) }\end{array}$ & $\begin{array}{l}\text { Group B 400mg/kg/day } \\
\text { Glyphosate }\end{array}$ & $\begin{array}{l}\text { Group C 2000mg/kg/day } \\
\text { Glyphosate }\end{array}$ \\
\hline $\begin{array}{l}\text { Follicle Stimulating Hormone } \\
(\mu I u / m l)\end{array}$ & $0.72 \pm 0.06$ & $0.62 \pm 0.02 *$ & $0.58 \pm 0.01 *$ \\
\hline Luteinizing Hormone $(\mu I u / m l)$ & $1.07 \pm 0.07$ & $1.09 \pm 0.08$ & $1.70 \pm 0.71 *$ \\
\hline Prolactin $(n g / m l)$ & $0.26 \pm 0.03$ & $0.26 \pm 0.03$ & $0.51 \pm 0.16^{*}$ \\
\hline Testosterone $(n g / m l)$ & $2.68 \pm 1.57$ & $1.65 \pm 0.67 *$ & $1.03 \pm 0.47 *$ \\
\hline Oestrogen $(\mathrm{pg} / \mathrm{ml})$ & $59.25 \pm 3.55$ & $62.43 \pm 7.22 *$ & $78.53 \pm 4.81 *$ \\
\hline Progesterone $(n g / m l)$ & $14.03 \pm 3.20$ & $14.48 \pm 3.55$ & $22.43 \pm 3.98 *$ \\
\hline Testosterone/Oestrogen ratio & $1: 2$ & $1: 4^{*}$ & $1: 8^{*}$ \\
\hline
\end{tabular}




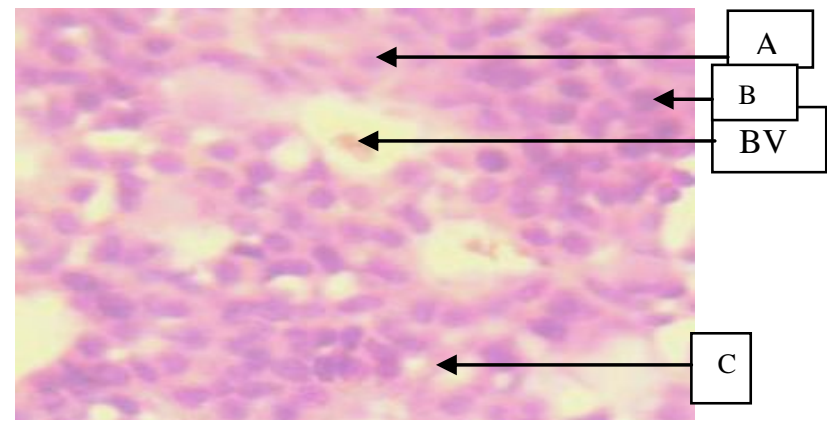

Figure 1: Photomicrograph of cross section of Adenohypophysis of Group A (Control) Wistar rat (x400; H \& E) illustrating normal chromophils (acidophils A, basophils B) and few chromophobes C (no affinity for histological stains). BV is a blood vessel.

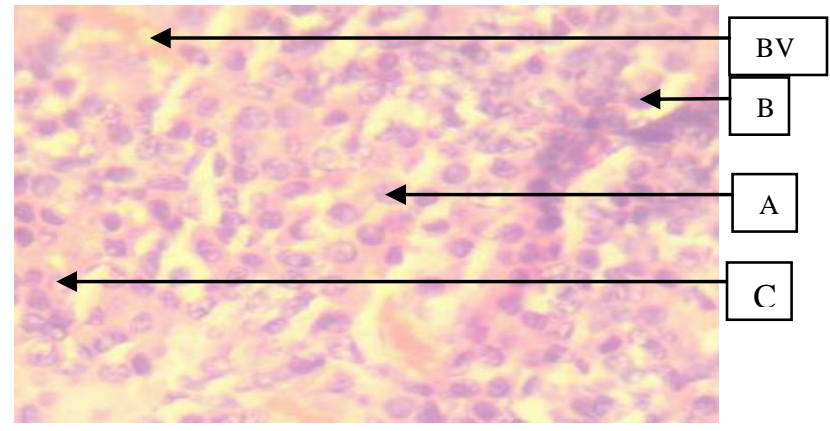

Figure 2: Photomicrograph of cross section of Adenohypophysis of Group B (400mg/kg body weight/day of glyphosate) Wistar rat (x400; H \& E) illustrating chromophils (acidophils A, basophils B) and few chromophobes $\mathrm{C}$ (no affinity for histological stains). BV is a blood vessel. There is hyperplasia of cells with mitotic bodies when compared with Fig. 1 (control).

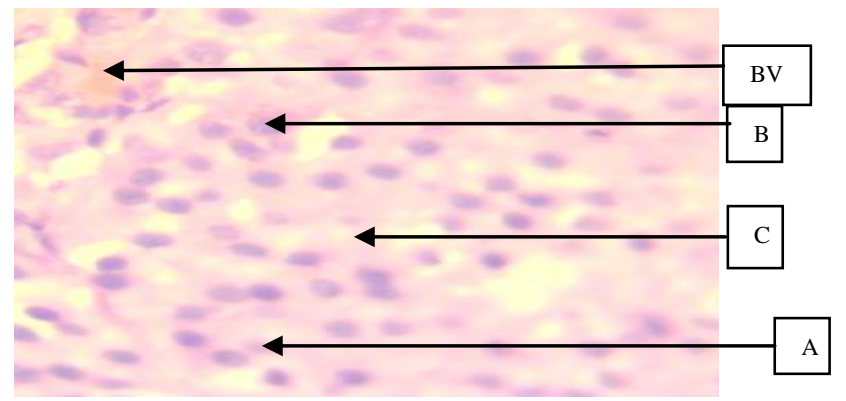

Figure 3: Photomicrograph of cross section of Adenohypophysis of Group C (2000mg/kg body weight/day of glyphosate) Wistar rat $(\mathrm{x} 400 ; \mathrm{H} \& \mathrm{E})$ illustrating chromophils (acidophils A, basophils B) and few chromophobes $\mathrm{C}$ (no affinity for histological stains). BV is a blood vessel. There is cellular hypoplasia with connective tissue separating the cells. Cells appear widely separated and fewer in number when compared with control group (Fig. 1).

\section{Discussion}

Experimenting with the use of glyphosate (as demonstrated in this study) and other common chemicals on rats serves as a guide in establishing their ecotoxicity and injurious effects on humans and animals. This study thereby will continue to provide objective measurement for acceptance from manufacturers and allows comparison of results among other researchers. ${ }^{5-9}$ The dose-dependent decrease in follicle stimulating hormone (FSH) following the increasing concentration of glyphosate showed that glyphosate might have penetrated the blood brain barrier (BBB) to inhibit FSH production from adenohypophysis. For the fact that luteinizing hormone $(\mathrm{LH})$ was concomitantly increasing meant that the biochemical effect of glyphosate on LH might be opposite to that of FSH at the level of the pituitary gland. On the other hand, the hypothalamus (median eminence) where common releasing hormone (GnRH) for FSH and LH is produced might have been involved. ${ }^{28,29}$ However, a further study will be needed to evaluate the releasing hormones from hypothalamus in other to settle the hypothesis: glyphosate either acts at the level of pituitary, hypothalamus or both.

Despite the fact that the mechanism of prolactin is not yet fully elucidated, hyperprolactinaemia significantly observed among male rats in group $\mathrm{C}$ was a pointer to anti-fertility effect of glyphosate. ${ }^{30,31}$ This observation also supported the fact that glyphosate did cross the $\mathrm{BBB}$ and acted on receptors either at the hypothalamus, pituitary or both levels to effect this change.

The statistically-significant decrease in concentration of serum testosterone with increasing dose of glyphosate and resultant feedback increase of LH value was an indicator to hormonal feedback by glyphosate as earlier propagated. ${ }^{19,} 32$ In another fashion, testosterone which is a drive to spermatogenesis and secondary sexual development might have been metabolized peripherally by glyphosate or reduced its production from the Leydig cells (LC) thereby calling for increase in LH to further stimulate the LC for the body to meet up with the needed testosterone.

Oestrogen is needed in the male reproductive tract for luminal fluid and ionic maintenance, nevertheless, the statistically-significant increasing serum oestrogen among the glyphosate-treated rats might have caused excessive accumulation of fluid in the tract, like other steroid hormones, to displace the sperms with resultant decrease in sperm density. ${ }^{33,34}$ On account of 
this inference, glyphosate might have acted on cytosolic steroid hormone receptors as a possible mechanism of action to this effect.

Progesterone is another steroid hormone needed as a receptor in acrosome reaction. ${ }^{29,} 35$ The possible increment of progesterone among the treated rats in the present study might have suggested a way out of finding the possible anti-fertility effect of glyphosate which was dose-dependent. This action was a potential negative feed-back mechanism following injurious effect of glyphosate on endocrine system. Majority of progesterone, likewise oestrogen, in male are either produced from the testis or conversion of other testicular steroid hormones within the reproductive tract. As a fraction of progesterone and oestrogen are produced from the suprarenal (adrenal) gland, glyphosate might have equally disrupted adrenal hormones as its endocrine disruptive chemical effects were now founded clearer in this study.

Testosterone-Oestrogen ratio further confirmed the fact that excess serum oestrogen concentration with respect to decrease serum testosterone concentration is a useful index in the evaluation of endocrine disruptive chemical effects of glyphosate with possible ant-fertility in males. The established screening programmes in the USA, UK and others will no doubt find this index a practicable tool in evaluating EDCs with respect to male reproductive tract.

As for the histological slides of group $\mathrm{C}$ rats, there were cellular hypoplasia compared to that of the control, glyphosate might have crossed the BBB to destroy those cells secreting FSH while sparing those for $\mathrm{LH}$ and prolactin with resultant decrease in serum concentration of FSH and increase in those of LH and prolactin. The deduction from these histological findings showed that glyphosate probably had a direct toxic effect on FSH producing cells in anterior pituitary, possibly through apoptotic or necrotic cellular death mechanism. At low dose group B, the hyperplasia noted might involve only cells producing LH. The aberrance in histology of treated rats (Figures 2 and 3 ) compared with control rats (Figure 1) agreed with the observed changes in the pituitary-gonadal axis hormones which also support the endocrine disruptive effect of glyphosate. Even though, the changes under light microscope appear very few, the state of the pituitary gland could be ascertained better with electron or other highly resolute microscope if available for the cellular ultra-structure. ${ }^{36}$

\section{Conclusion}

Male reproductive hormones were disrupted among glyphosate-treated Wistar rats. This study hereby joins other researchers to establish the fact that glyphosate is an endocrine disrupting chemical (EDC). Histological slides of glyphosate-treated rats show some level of abnormality, notwithstanding, investigation using high-resolute imaging will prove better.

\section{Recommendation}

As glyphosate is now proven to be EDC, the use in different countries should be guided with a policy favourably on health (which is considered to be wealth) of humans and other animals in the ecosystem. Otherwise, banning of glyphosate as obtained in some countries should be the order.

\section{Limitation}

Only light microscope was available to imaging the pituitary gland.

\section{Acknowledgment}

The authors use this medium to thank Dr Ataman J, Dr Eze G and Prof Grillo D B of the Department of Anatomy, University of Benin, Benin-City, Nigeria for going through the manuscript with useful contribution.

\section{Formatting of funding sources}

This research did not receive any specific grant from funding agencies in the public, commercial, or notfor-profit sectors.

\section{Conflict of interests}

The authors declare no conflict of interests.

\section{References}

1. Mnif W, Hassine A H, Bouaziz A, Bartegi A, Thomas O, Roig B. Effect of Endocrine Disruptor Pesticides: A Review. Int J Environ Res Public Health 2011;8(6): 2265-2303.

2. Colborn T, vom Saal F S, Soto A M. Developmental effects of endocrine-disrupting chemicals in wildlife and humans. Environ Health Perspect 1993;101: 378-384.

3. Wirbisky S E, Freeman J L. Atrazine Exposure and Reproductive Dysfunction through the HypothalamusPituitary-Gonadal (HPG) Axis. Toxics 2015;3(4): 414-450.

4. Walsh L P, McCormick C, Martin C, Stocco D M. Roundup inhibits steroidogenesis by disrupting steroidogenic acute 
regulatory (StAR) protein expression. Environ Health Perspect 2000;108(8): 769-776.

5. Gasnier C, Dumont C, Benachour N, Clair E, Chagnon M C, Seralini G E. Glyphosate-based herbicides are toxic and endocrine disruptors in human cell lines. Toxicology 2009;262(3): 184-191.

6. Romano M A, Romano R M, Santos L D, Wisniewski P, Campos D A, de Souza P B, et al. Glyphosate impairs male offspring reproductive development by disrupting gonadotropin expression. Arch Toxicol. 2012;86(4): 663673.

7. Thongprakaisang S, Thiantanawat A, Rangkadilok N, Suriyo T, Satayavivad J. Glyphosate induces human breast cancer cells growth via estrogen receptors. Food Chem Toxicol. 2013;59c: 129-136.

8. Copping L G. Post-emergent herbicides, Agrow Report DS230, 2002: 180 .

9. Cerdeira A L, Gazziero D L P, Duke S O, Matallo M B, Spadotto C A. Review of potential environmental impacts of transgenic glyphosate-resistant soybean in Brazil. Journal of Environmental Science and Health 2007;42: 539-549.

10. Watts M, Williamson S. Replacing Chemicals with Biology: Phasing out highly hazardous pesticides with agroecology. Pesticide Action Network Asia and the Pacific 2015: 48-68.

11. Shaner D. An overview of glyphosate mode of action: why is it such a great herbicide? North Central Weed Science Society Proceedings 2006;61: 94.

12. 12, Gammon C. Weed-whacking herbicide proves deadly to human cells. Environmental Health News 2009: 96.

13. Drury B, Rosi-Marshall E, Kelly J J (2013). Wastewater Treatment Effluent Reduces the Abundance and Diversity of Benthic Bacterial Communities in Urban and Suburban Rivers Appl Environ Microbiol 2013;79(6): 1897-1905.

14. Shaner D L, Nadler-Hussar T, Henry W B, Koger C H. A rapid in vivo shikimate accumulation assay with excised leaf discs. Weed Science 2005;53(6): 769-774.

15. Ermak G, Davies K J A. Calcium and oxidative stress: from cell signalling to cell death. Molecular Immunology 2002;38: 713-721.

16. Cavalli V L L O, Cattani D, Rieg C E H, Pierozan P, Zanatta L, Parisotto E B, Filho D W, Silva F R M B, Pessoa-Pureur R and Zamoner A. Roundup disrupts male reproductive functions by triggering calcium-mediated cell death in rat testis and Sertoli cells. Free Radical Biology and Medicine 2013;65: 335-346.

17. Lemasters J L, Nieminen A, Qian T, Trost L C, Elmore S P, Nishimura Y, Crowe R A, Cascio W E, Bradham C A, Brenner D A, Herman B. The mitochondrial permeability transition in cell death: a common mechanism in necrosis, apoptosis and autophagy. Biochimica et Biophysica Acta (BBA) - Bioenergetics 1998;366(12): 177-196.

18. Zhivotovsky B, Orrenius S. Calcium and cell death mechanism: A perspective from the cell death community. Cell Calcium 2011;50: 211-221.

19. Dallegrave E, Mantese F D, Oliveira R T, Andrade A J, Dalsenter P R and Langeloh A. Pre- and postnatal toxicity of the commercial glyphosate formulation in Wistar rats. Archives of Toxicology 2007;81: 665-673.

20. Anadon A, Martínez-Larrañaga $M \quad R$, Martínez $M$ A, Castellano V J, Martínez M, Martin M T, Nozal M J, Bernal J L. Toxicokinetics of glyphosate and its metabolite aminomethyl phosphonic acid in rats. Toxicology Letters 2009;190(1): 91-95.

21. Carlisle S M, Trevors. J T. Glyphosate - Canadian Environmental Quality Guidelines. Canadian Council of Ministers of the Environment. Excerpt from Publication 2012; No. 1299 ISBN 1-896997-34-1.

22. GMWatch. Roundup is an endocrine disruptor - new study $2015 . \quad$ http://gmwatch.org/en/news/latest-news/16353roundup-is-an-endocrine-disruptor-new-study. Accessed: 04/05/2017.

23. Glyphosate Saga: independent scientific advice 2015. https://corporateeurope.org/food-and agriculture/2015/04/glyphosate-sag. Accessed: 04/09/2017.

24. 24. United States Environmental Protection Agency (1993). Office of Pesticide Programs. Special Review and Reregistration Division. Reregistration eligibility decision (RED): Glyphosate. Washington District of Columbia (September) 1993. Available from :http://web.net/nwatch/fmp/workshops/herbicideworkshop/Gl yphosate.pdf. Accessed: 30/08/2016.

25. 25. Cox C. Glyphosate, Part 1: Toxicology. Journal of Pesticide Reform 1995;15(3): 1-27.

26. 26. Ikebuaso A D, Yama O E, Duru F I O, Oyebadejo S A. Experimental Testicular Torsion in a Rat Model: Effects of Treatment with Pausinystalia macroceras on Testis Functions. Journal of Reproduction and Infertility 2012;13(4): 218-224.

27. 27. Lequin R M. Perspective on the Historical Note on EIA/ELISA. Clinical Chemistry 2005;51(12): 2225.

28. 28. Guyton A C, Hall J E. Textbook of Medical Physiology. $11^{\text {th }}$ edition. Elsevier Saunders 2006: 1032-1046.

29. Young B, Lowe J S, Stevens A. Male reproductive system. In: Wheater's Functional Histology. 5ed Elsevier 2007b: 346358.

30. Gill-Sherman M K. Prolactin and Male Fertility: The Long and Short Feedback Regulation. International Journal of Endocrinology. Volume 2009 (2009), Article ID 687259, 13 pages.

31. Saito T R, Olah M, Terada M, Nagy G M. The Role of Prolactin in the Regulation of Male Copulatory Behavior. Intech U S A 2013. http://dx.doi.org/10.5772/55515. Accessed: 29/08/2016.

32. Romano R M, Romano M A, Bernadi M M, Furtado P V and Oliveira C A. Prepubertal exposure to commercial formulation of the herbicide and decreased testosterone serum level at puberty alters testosterone levels and testicular morphology. Archives of Toxicology 2010;84: 309-317.

33. Robertson K M, O'Donnell L, Simpson E R, Jones M E. The phenotype of the aromatase knockout mouse reveals dietary phytoestrogens impact significantly on testis function. Endocrinology 2002;143: 2913-2921.

34. Hess R A. Estrogen in the adult male reproductive tract: A review. Reproductive Biology and Endocrinology 2003;1: 52.

35. Shah C, Rosario G, Sachdeva G, Puri C. Progesterone receptors on human spermatozoa. Indian Journal of Experimental Biology 2003;41(7): 773-780.

36. Young B, Lowe J S, Stevens A. Endocrine system (Pituitary gland). In: Wheater's Functional Histology. 5ed Elsevier 2007a: 328-332. 